\title{
BAGAIMANA MEMUDAHKAN PESERTA DIDIK MEMPELAJARI MODUL?
}

Oleh: Sudirman Siahaan *

\section{Abstrak}

Bahan belajar mandiri cetak atau yang disebut modul merupakan bahan belajar utama yang dikembangkan oleh sebagian besar institusi/lembaga penyelenggara pendidikan terbuka dan jarak jauh untuk digunakan membelajarkan para peserta didiknya. Modul tidak hanya berisikan materi pembelajaran (self-contained) tetapi juga memuat berbagai petunjuk/penjelasan tentang caracara mempelajari modul dan ruang atau tempat bagi peserta didik untuk melakukan penilaian sendiri mengenai kemajuan belajarnya (learning guides and steps). Selama mempelajari modul, peserta didik senantiasa dimotivasi/didorong untuk terusmenerus aktif mempelajari modul termasuk mengerjakan soalsoal latihan/tugas dan tes. Umpan balik terhadap hasil pekerjaan peserta didik juga terdapat di dalam modul. Petunjuk/penjelasan yang terdapat di dalam modul dimaksudkan untuk membantu mempermudah peserta didik mempelajari dan menguasai materi pembelajaran. Petunjuk/penjelasan tentang cara-cara mempelajari modul atau yang disebut juga sebagai "petunjuk belajar" dinilai sangat penting dalam menentukan keberhasilan peserta didik belajar. Mengapa? Karena kegiatan pembelajaran pada pendidikan terbuka dan jarak jauh hampir sepenuhnya dilaksanakan peserta didik melalui interaksinya dengan sumber belajar, tanpa atau dengan seminimal mungkin bantuan orang lain. Terlebih lagi apabila modul ditujukan kepada peserta didik usia pendidikan dasar dan menengah. Esensi kegiatan belajar yang demikian inilah yang harus benar-benar diperhatikan oleh

*) Drs. Sudirman Siahaan, M.Pd., adalah tenaga fungsional peneliti bidang pendidikan pada Pustekkom Depdiknas 
penulis modul. Tulisan tentang "Bagaimana Memudahkan Peserta Didik Mempelajari Modul?" ini dinilai penting karena membahas hal-hal praktis yang diharapkan akan dapat membantu penulis modul merumuskan/memberikan cara-cara dan langkah-langkah mempelajari modul.

Kata Kunci: modul, belajar mandiri, petunjuk belajar

\section{A. PENDAHULUAN}

"Bagaimana Memudahkan Peserta Didik Mempelajari modul?" merupakan satu topik yang bersifat praktis yang diharapkan akan dapat membantu membekali penulis/calon penulis modul atau seseorang yang berminat untuk mempelajari cara-cara merumuskan petunjuk belajar dan langkah-langkah mempelajari modul. Memang masih ada beberapa topik lainnya yang membahas tentang caracara membantu mempermudah peserta didik mempelajari modul, yaitu antara lain perancangan dan penggunaan ilustrasi yang memadai (Purwanto, 2000), penggunaan bahasa yang komunikatif (Inten, 2000), penggunaan kalimat yang sederhana (Haryono, 2001), penggunaan contoh (Rahardjo, 2001). Yang menjadi fokus bahasan di dalam tulisan ini terbatas pada cara-cara atau petunjuk belajar dan langkah-langkah mempelajari modul sehingga dapat membantu mempermudah peserta didik mempelajari modul. Sekalipun memang keterlibatan aspek mental sangat besar di dalam mempelajari modul, namun aspek fisik juga tidaklah menjadi terlupakan (Andamsari, 2000).

Tulisan ini merupakan salah satu referensi bagi penulis/calon penulis modul dalam menulis modul. Topik tulisan ini dinilai penting untuk dibahas karena modul pada hakekatnya adalah bahan belajar mandiri tercetak yang dapat dipelajari oleh peserta didik secara independen, baik secara individual maupun dalam kelompok kecil, tanpa atau dengan seminimal mungkin bantuan orang lain (Haryono, 2001). Karena itu, penulis modul haruslah mampu merumuskan sesederhana mungkin cara-cara atau langkah-langkah mempelajari modul 
sehingga mudah dipahami oleh peserta didik yang mempelajari modul. Sekaligus juga mengantisipasi kemungkinan terjadinya kesulitan yang dihadapi peserta didik dalam mempelajari modul. Terlebih lagi apabila modul ditujukan kepada peserta didik usia pendidikan dasar dan menengah.

Kekurangpahaman peserta didik tentang cara-cara dan langkahlangkah mempelajari modul atau kekurangjelasan cara-cara dan langkah-langkah mempelajari modul yang dirumuskan dapat "menggoda" peserta didik untuk tidak tertib mempelajari modul. Sebagai contoh tentang ketidaktertiban peserta didik adalah godaan untuk tidak berupaya seoptimal mungkin mempelajari uraian materi pelajaran dan mengerjakan soal-soal tugas/latihan dan tes yang diberikan. Kecenderungan lainnya adalah melihat langsung Kunci Jawaban terhadap soal-soal tugas/latihan dan tes yang pada umumnya tersedia pada bagian akhir modul. Contoh lain lagi adalah kecenderungan peserta didik untuk langsung mempelajari rangkuman yang ada di dalam modul dan kemudian mengerjakan soal-soal tugas/ latihan dan tes yang diberikan. Kecenderungan sikap yang demikian ini (belum berkembangnya sikap kejujuran terhadap diri sendiri) di kalangan sebagian peserta didik perlu disiasati oleh para penulis modul.

Memang tidak ada garansi apabila cara-cara dan langkah-langkah mempelajari modul telah dirumuskan secara jelas di dalam modul, maka peserta didik akan mempelajari modul sesuai dengan caracara dan langkah-langkah yang diberikan. Godaan untuk menempuh jalan pintas mempelajari modul senantiasa terbuka. Sekalipun tidak ada yang dapat menjamin bahwa peserta didik akan mempelajari modul sesuai dengan cara dan langkah yang diberikan, tetapi setidaktidaknya akan dapat menggugah peserta didik setiap saat membaca cara dan langkah mempelajari modul. Memang masih ada upaya lain yang dapat ditempuh penulis modul agar peserta didik dapat lebih aktif mempelajari modul, yaitu penulisan modul yang disesuaikan dengan karakteristik modul, seperti: penggunaan ilustrasi dan penggunaan bahasa yang komunikatif. Namun pembahasan di 
dalam tulisan ini hanya berfokus pada perumusan cara-cara memotivasi atau mendorong peserta didik agar lebih mudah dan berhasil mempelajari modul.

Pada dasarnya, keberhasilan belajar peserta didik pendidikan terbuka dan jarak jauh sangat ditentukan oleh kesadaran, kemauan keras, dan disiplin yang tinggi dalam belajar mandiri. Karena itu, kegiatan belajar peserta didik akan lebih terarah dalam mempelajari modul apabila peserta didik dapat memahami secara jelas cara-cara dan langkah-langkah mempelajari modul yang telah dirumuskan. Di samping itu, pemberian appersepsi, appresiasi, motivasi, dan salutasi diharapkan akan dapat menggugah dan mendorong peserta didik untuk meningkatkan motivasinya mempelajari modul.

Sehubungan dengan uraian mengenai essensi cara-cara dan langkahlangkah mempelajari modul, maka para penulis modul dalam menulis modul hendaknya selalu cermat untuk menuliskan cara dan langkah mempelajari modul. Tentunya diharapkan bahwa peserta didik akan merasakan "seolah-olah penulis modul berbicara langsung dengan peserta didik" sewaktu mereka mempelajari modul. Dengan demikian, peserta didik akan tergugah untuk lebih aktif mempelajari modul. Karena itu, tulisan ini setidak-tidaknya akan membantu membekali para penulis modul dalam merumuskan cara-cara dan langkahlangkah mempelajari modul yang mengarah pada pengkondisian peserta didik untuk lebih aktif mempelajari modul.

\section{B. PEDOMAN MENULIS MODUL AGAR MEBANTU MEMPERMUDAH PESERTA DIDIK MEMPELAJARI MODUL}

\section{Perumusan Cara-cara atau Petunjuk dalam Mempelajari Modul}

Mengapa penulis modul perlu mempelajari cara-cara belajar dengan modul (petunjuk belajar)? Atau, dengan pertanyaan lain, apa jadinya seandainya sebuah modul tidak mempunyai petunjuk 
pemanfaatan modul (petunjuk belajar) yang jelas bagi orang yang mempelajarinya? Tentulah peserta didik akan mengalami kesulitan mempelajari modul. Kesulitan mempelajari modul yang dihadapi akan dapat mengakibatkan menurunnya motivasi belajar peserta didik. Motivasi belajar yang menurun akan dapat pula berpengaruh pada tingkat keberhasilan belajar peserta didik. Jelaslah tampak betapa penting dan menentukannya cara-cara atau petunjuk belajar di dalam bahan belajar mandiri (modul) (Sadiman, 1987). Petunjuk belajar perlu dipelajari dan dipahami peserta didik terlebih dahulu sebelum mempelajari materi pembelajaran yang disajikan di dalam modul.

Adalah benar bahwa cara-cara atau petunjuk belajar perlu ditempatkan pada bagian awal setiap modul. Mengapa demikian? Karena tujuannya adalah agar para peserta didik mengetahui terlebih dahulu secara jelas bagaimana seharusnya mereka mempelajari modul. Dengan diketahuinya secara jelas cara-cara mempelajari modul, tentunya akan dapat membantu mempermudah peserta didik memahami/menguasai materi pembelajaran yang diuraikan di dalam modul. Tetapi, apakah cukup jika cara-cara atau petunjuk belajar hanya ditempatkan pada bagian awal modul? Jawabannya tentulah tidak.

Cara-cara atau petunjuk belajar tidak hanya diperlukan pada bagian awal modul tetapi diperlukan juga di dalam uraian materi modul itu sendiri. Mengapa? Karena melalui cara-cara atau petunjuk belajar, peserta didik dimotivasi untuk terus-menerus aktif melakukan kegiatan belajarnya. Misalnya, peserta didik diperkirakan akan mengalami kesulitan pada bagian materi tertentu yang terdapat di dalam modul. Pada bagian yang demikian ini perlu diberikan cara-cara atau petunjuk belajar. Tujuannya adalah agar peserta didik yang mengalami kesulitan belajar merasa mendapat dorongan/motivasi yang membesarkan hatinya untuk mencari solusi sehingga dapat meneruskan kegiatan belajarnya. Melalui cara-cara atau petunjuk belajar ini, peserta 
didik diarahkan untuk tidak mudah berputus asa. Semangat belajar peserta didik haruslah selalu ditumbuh-kembangkan dan dipertahankan untuk tidak menurun selama mempelajari modul (Siahaan, 2004).

Berikut ini disajikan sebuah contoh tentang cara-cara atau petunjuk belajar yang berkaitan dengan bagian materi modul yang diperkirakan sulit dipahami peserta didik.

Sejauh ini, apakah Anda mengalami kesulitan? Jika YA, mengapa Anda tidak mencoba mempelajari kembali materi pelajaran yang baru saja Anda pelajari? Yakinkan diri Anda bahwa Anda pasti dapat mengatasi kesulitan yang Anda hadapi. Ingatlah bahwa keberhasilan mengatasi kesulitan akan lebih memantapkan rasa percaya diri. Sekalipun Anda misalnya sudah berusaha tetapi kesulitan/ masalahnya masih belum juga teratasi, mengapa tidak mencoba mendiskusikannya dengan teman atau orang lain yang mungkin dapat membantu Anda? Tentulah Anda akan dengan senang hati melakukannya bukan? Ajaklah 2 atau 3 orang teman untuk berdiskusi tentang kesulitan yang Anda hadapi.

Selanjutnya, hal-hal apa saja yang perlu diperhatikan penulis dalam menuliskan cara-cara atau petunjuk belajar yang dapat membantu mempermudah peserta didik mempelajari modul? Khusus yang berkaitan dengan petunjuk belajar, ada 3 hal yang perlu diperhatikan, yaitu: (a) penempatan petunjuk belajar, (b) kapan petunjuk belajar diberikan, dan (c) tips dalam menuliskan cara-cara atau petunjuk belajar dalam mempelajari modul. Selain ketiga hal ini, langkah-langkah mempelajari modul juga akan menjadi materi bahasan di dalam tulisan ini. 


\section{a. Petunjuk Belajar}

1) Penempatan Petunjuk Belajar di dalam Modul

a) Petunjuk Belajar Diperlukan pada Awal Modul Sebagaimana yang telah dikemukakan sebelumnya bahwa cara-cara atau petunjuk belajar dalam mempelajari modul terdapat pada bagian awal modul dan juga pada uraian materi modul. Pada sistematika/ format modul, bagian awal modul disebut sebagai PENDAHULUAN. Pada bagian PENDAHULUAN inilah dijelaskan secara garis besar tentang bagaimana cara-cara mempelajari modul. Karena itu, penulis modul haruslah dapat menguraikan "cara-cara atau petunjuk mempelajari modul" sejelas mungkin dan memadai.

Agar "cara-cara atau petunjuk belajar dalam mempelajari modul" yang disusun dapat membantu memudahkan peserta didik mempelajari modul, maka penulis modul haruslah memposisikan dirinya sebagai peserta didik yang akan mempelajari modul itu sendiri. Melalui pemikiran yang demikian ini, maka "cara-cara atau petunjuk belajar" yang disusun diharapkan akan dapat membantu mempermudah peserta didik mempelajari modul. Implikasi lebih jauh dari petunjuk belajar yang sederhana dan jelas adalah pada tingkat keberhasilan belajar peserta didik.

Apabila dicermati uraian yang dikemukakan pada bagian PENDAHULUAN dari setiap modul, maka akan ditemukan uraian tentang judul modul, ruang lingkup materi modul, tujuan pembelajaran, langkahlangkah memperlajari modul, beberapa penekanan khusus untuk diperhatikan peserta didik, tips yang memotivasi peserta didik untuk aktif belajar, ucapan selamat berjumpa dalam modul, dan ucapan "SELAMAT BELAJAR" kepada peserta didik. Pada 
bagian akhir dari PENDAHULUAN, penulis modul juga pada umumnya menyampaikan harapannya kepada peserta didik agar mereka SUKSES MEMPELAJARI MODUL.

b) Petunjuk Belajar pada Uraian Materi Modul Setelah mempelajari "cara-cara atau petunjuk belajar" yang terdapat pada bagian awal modul, maka peserta didik telah dikondisikan agar menerapkan "cara-cara atau petunjuk belajar" tersebut selama mempelajari modul. Namum berdasarkan pengalaman, para peserta didik masih tetap membutuhkan "cara-cara atau petunjuk belajar" dalam mempelajari uraian materi pembelajaran yang disajikan di dalam setiap Kegiatan Belajar yang terdapat pada modul. Tujuannya adalah agar motivasi atau semangat belajar peserta didik tidak mengalami kemunduruan. Motivasi/semangat belajar yang dapat dipertahankan secara terus-menerus atau bahkan ditingkatkan akan menjadi salah satu faktor yang turut menentukan keberhasilan belajar peserta didik.

2) Kapan Diberikan Petunjuk Belajar di dalam Modul? Ada beberapa kondisi yang dinilai penting untuk memberikan cara atau petunjuk belajar kepada peserta didik yang mempelajari modul, yaitu:

a) Pada saat peserta didik mempelajari bagian awal modul atau PENDAHULUAN

Ada beberapa petunjuk belajar yang perlu dikemukakan pada bagian PENDAHULUAN dari suatu modul. Misalnya tentang tujuan pembelajaran atau kompetensi yang akan dicapai setelah selesai mempelajari modul, ruang lingkup materi yang dicakup, langkah-langkah yang perlu diperhatikan peserta didik dalam mempelajari modul, dan tindak lanjut setelah selesai mempelajari modul. Berikut ini 
akan diberikan beberapa contoh petunjuk belajar pada bagian PENDAHULUAN modul yang perlu dipertimbangkan oleh penulis modul.

(1) Contoh tentang petunjuk belajar yang berkaitan dengan langkah-langkah mempelajari modul.

Modul ini disusun menjadi 3 Kegiatan Belajar. Setiap Kegiatan Belajar dilengkapi dengan soal-soal tugas/latihan. Melalui soal-soal latihan/tugas dan tes yang Anda kerjakan dengan sungguh-sungguh akan memungkinkan Anda menguasai materi pelajaran yang disajikan pada modul. Mulailah dengan Kegiatan Belajar 1. Setelah selesai mempelajari semua materi pembelajaran yang diuraikan pada ketiga Kegiatan Belajar, mintalah waktu kepada tutor/fasilitator untuk mengerjakan Tes Akhir Modul (TAM).

(2) Contoh tentang petunjuk belajar yang berkaitan dengan tujuan pembelajaran atau kompetensi yang akan dicapai peserta didik setelah selesai mempelajari modul .

Setelah selesai mempelajari modul ini, Anda akan dapat: (1) menjelaskan pengertian, karakteristik, dan format/sistematika modul; (2) membedakan modul dengan buku teks; dan (3) menjelaskan prinsip-prinsip penulisan modul. 
(3) Contoh tentang petunjuk belajar yang berkaitan dengan ruang lingkup materi pelajaran yang dicakup di dalam modul.

Materi pelajaran yang diuraikan di dalam modul ini terdiri atas 3 Kegiatan Belajar yang akan membahas (a) pengertian, karakteristik dan format/sistematika modul, (b) prinsipprinsip penulisan/ pengembangan modul, dan (c) prosedur/langkah-langkah penulisan modul. Pada setiap Kegiatan Belajar terdapat pengantar, uraian materi, dan rangkuman. Setiap Kegiatan Belajar dilengkapi dengan soal-soal tugas/latihan. Mulailah dengan Kegiatan Belajar-1. Selamat Belajar dan semoga sukses!

(4) Contoh tentang petunjuk belajar yang berkaitan dengan pemberian motivasi kepada peserta didik dalam mempelajari modul.

Belajar melalui modul tidaklah sulit asalkan Anda mempelajarinya dengan sungguhsungguh dan cermat mengikuti petunjuk belajar yang diberikan. Anda dapat mempelajari bagian tertentu berulang kali sampai kita benar-benar memahami materi pelajaran yang dibahas. Tidak perlu merasa malu apabila Anda lebih lambat menyelesaikan sebuah modul. Anda tidak perlu ragu menemui seseorang untuk mendiskusikan materi tertentu yang terdapat di dalam modul ini yang kemungkinan sulit Anda pahami. Ingatlah bahwa "Di mana ada kemauan, di situ ada jalan". Selamat belajar! 
b) Pada saat peserta didik mempelajari uraian materi pelajaran yang dibahas di dalam Kegiatan Belajar

(1) Contoh petunjuk belajar yang disajikan pada bagian pengantar dari suatu Kegiatan Belajar

Jika Anda diminta untuk mengerjakan sesuatu, misalnya menuliskan pendapat atau melengkapi isian tertentu di dalam modul ini, maka segeralah hal tersebut Anda kerjakan. Kerjakanlah dengan serius/tekun. Jangan sekali-kali mencoba menunda untuk mengerjakannya. Setelah Anda selesai mempelajari materi yang diuraikan dan merasa benar-benar telah memahaminya, maka kerjakanlah soal-soal tugas/latihan yang disediakan. Usahakan untuk tidak sekali-kali melihat Kunci Jawaban yang disediakan sebelum selesai mengerjakan semua soal tugas/latihan. Jika Anda tidak bersikap jujur dalam hal ini, maka yang rugi adalah diri Anda sendiri. 
(2) Contoh lainnya dari petunjuk belajar yang disajikan pada bagian pengantar suatu Kegiatan Belajar

Setelah selesai mempelajari materi yang diuraikan pada Kegiatan Belajar 1 ini, Anda diminta untuk mencamkan rangkuman materi pelajaran yang terdapat pada bagian akhir dari uraian materi. Anda juga dimungkinkan untuk memberikan tambahan terhadap materi rangkuman. Setelah itu, kerjakanlah soal-soal latihan/tugas yang diberikan. Anda tidak dibenarkan untuk melanjutkan kegiatan belajar mempelajari materi pelajaran yang terdapat pada Kegiatan Belajar 2 apabila Anda belum berhasil mengerjakan soal-soal latihan/ tugas yang diberikan minimal $75 \%$ benar.

(3) Pada saat peserta didik diberikan soal-soal latihan/tugas atau tes untuk dikerjakan Apakah yang harus diperhatikan peserta didik dalam mengerjakan soal-soal latihan/tugas (tes) yang diberikan pada setiap akhir Kegiatan Belajar? Dalam kaitan ini, petunjuk belajar yang diberikan hendaknya dapat meyakinkan peserta didik agar tidak sekalikali melihat Kunci Jawaban yang ada sebelum semua soal latihan/tugas atau tes selesai dikerjakan. Di samping itu, peserta didik barulah dipersilakan untuk memeriksa hasil pekerjaannya dengan menggunakan Kunci Jawaban.

Contoh petunjuk belajar yang berkaitan dengan dengan soal-soal latihan/ tugas (tes). 
Cobalah kerjakan sendiri soal-soal latihan/ tugas (tes) berikut ini dengan cermat. Usahakanlah untuk mengerjakan semua soal latihan/tugas (tes) yang diberikan. Setelah selesai, periksalah jawaban Anda dengan menggunakan Kunci Jawaban yang disediakan pada bagian akhir modul ini. Namun jangan sekali-kali melihat Kunci Jawaban sebelum Anda selesai mengerjakan semua soal latihan/tugas (tes) karena akan merugikan diri Anda sendiri. Semoga berhasil.

(4) Petunjuk belajar yang berkaitan dengan tindak lanjut yang perlu dilakukan peserta didik setelah mengetahui hasil yang dicapai dalam mengerjakan soal-soal latihan/tugas (tes). Apa yang perlu dilakukan peserta didik setelah mengetahui hasil yang dicapai dalam mengerjakan soal-soal latihan (tes)? Apakah peserta didik diperkenankan untuk mempelajari materi yang diuraikan pada Kegiatan Belajar berikutnya? Ataukah, peserta didik perlu didorong atau diyakinkan untuk mempelajari ulang materi pelajaran yang baru selesai dipelajarinya terutama materi pelajaran yang masih belum dipahami.

Sehubungan dengan tindak lanjut yang perlu dilakukan peserta didik, berikut ini diberikan contoh petunjuk belajar agar peserta didik melakukan tindak lanjut setelah mengetahui hasil yang dicapai dalam mengerjakan soal-soal latihan (tes). 
Bagaimana hasil pekerjaan Anda? Tidak terlalu sulit soal-soal latihannya bukan? Tentulah Anda telah berhasil menjawab semua soal latihan/tugas dengan benar atau setidaktidaknya $75 \%$ benar. Jika Ya, lanjutkanlah mempelajari modul pada bagian berikutnya. Namun, seandainya BELUM, Anda tidak perlu merasa malu atau menjadi kendor semangat belajarnya. Cobalah pelajari ulang secara lebih cermat materi pembelajaran yang baru selesai Anda pelajari terutama bagian materi pembelajaran yang benar-benar belum Anda pahami. Yakinkan diri Anda bahwa Anda pasti akan berhasil. Semoga Anda berhasil.

(5) Petunjuk belajar yang perlu diberikan yang berkaitan dengan tindak lanjut untuk mengerjakan Tes Akhir Modul (TAM) sebagai syarat untuk dapat mempelajari modul berikutnya.

Selamat! Anda baru saja selesai mempelajari materi pelajaran yang dibahas di dalam modul ini. Untuk dapat melanjutkan kegiatan belajar Anda ke modul berikutnya, temuilah tutor/ fasilitator agar Anda diberikan waktu untuk mengerjakan Tes Akhir Modul (TAM). Nah, persiapkan diriAnda dengan sebaik-baiknya agar Anda dapat berhasil mengerjakan TAM dengan hasil yang memuaskan atau setidak-tidaknya mencapai standar keberhasilan yang minimal. Tanyakanlah sekaligus kepada tutor/fasilitator, kapan dapatAnda memperoleh hasil TAM. Sekali lagi, hanya dengan persiapan yang matang, Anda akan berhasil mengarjakan TAM. Selamat Mempersiapkan diri dan Semoga sukses! 
3) Tujuan Merumuskan Cara-cara atau Petunjuk Belajar di dalam Modul

Pada uraian sebelumnya dikemukakan bahwa cara-cara atau petunjuk belajar dan langkah-langkah dalam mempelajari modul tidak hanya perlu diberikan pada bagian PENDAHULUAN tetapi juga pad URAIAN MATERI yang terdapat pada setiap Kegiatan Belajar. Tujuan apa yang akan dicapai dengan merumuskan cara-cara atau petunjuk belajar dan langkah-langkah di dalam modul? Berikut ini dikemukakan beberapa tujuan dirumuskannya cara-cara atau petunjuk belajar dan langkah-langkah di dalam modul.

a) Menggugah atau memotivasi peserta didik untuk mempelajari ulang materi pembelajaran yang baru saja selesai dipelajari

Ada kecenderungan di kalangan sebagian peserta didik untuk tidak cermat memperhatikan standar minimal penguasaan materi pelajaran pada masingmasing penggalan belajar atau kegiatan belajar yang terdapat di dalam modul. Karena itu, penulis modul haruslah cermat mengingatkan peserta didik melalui petunjuk belajar yang diberikan agar peserta didik mengikuti petunjuk belajar demi kepentingannya sendiri.

Pada kotak di bawah ini, diberikan sebuah contoh petunjuk belajar yang bertujuan mendorong atau memotivasi peserta didik untuk mempelajari ulang materi pembelajaran yang baru saja selesai dipelajarinya. 
Jika seandainya Anda belum berhasil menjawab soal-soal latihan/tugas $75 \%$ benar, berarti Anda belum diperkenankan untuk mempelajari Kegiatan Belajar berikutnya. Walau demikian, Anda tidak perlu merasa malu atau menjadi kendor semangat belajarnya. Cobalah pelajari ulang secara lebih cermat materi pelajaran yang baru saja selesai Anda pelajari terutama bagian materi pelajaran yang benar-benar belum Anda pahami. Yakinkan diri Anda bahwa Anda pasti akan berhasil. Semoga Anda berhasil.

b) Memberikan kesempatan kepada peserta didik untuk lebih memantapkan pemahamannya tentang hal-hal penting yang telah diuraikan

Agar peserta didik dapat menyimpan inti materi pembelajaran yang telah dipelajari dengan lebih baik dan tahan lebih lama di dalam memorinya, maka dipandang perlu untuk memberikan petunjuk belajar sebelum peserta didik beralih/berpindah ke pembahasan materi pembelajaran berikutnya. Contoh yang diberikan di bawah ini dapat ditambahkan atau disempurnakan sehingga peserta didik lebih termotivasi untuk lebih memantapkan pemahamannya tentang hal-hal penting yang telah diuraikan.

Hendaknya di dalam benak penulis modul berkembang pemikiran "apakah dengan membaca petunjuk belajar yang diberikan, peserta didik akan merasa termotivasi atau diberi kesempatan untuk memantapkan pemahamannya tentang hal-hal penting yang telah diuraikan?" Dalam kaitan ini, yang tetap dipegang teguh oleh penulis modul adalah apakah peserta didik dapat dengan mudah 
memahami petunjuk belajar yang diberikan atau tidak.

Contoh petunjuk belajar yang bertujuan memberikan kesempatan kepada peserta didik untuk lebih memantapkan pemahamannya tentang hal-hal penting yang telah diuraikan.

Sampai sejauh ini, diharapkan pemahaman Anda mengenai konsep tentang modul sudah jelas. Nah, untuk lebih memantapkan pemahaman Anda tentang konsep mengenai modul, cobalah rumuskan dengan menggunakan bahasa Anda sendiri pengertian mengenai modul pada kotak berikut ini.

\section{Modul adalah}

c) Mendorong/memotivasi peserta didik agar tergerak hati dan pikirannya untuk berbagi pengetahuan/ pendapatnya dengan orang lain

Tentunya kita masih belum merasa puas apabila peserta didik hanya mampu memahami materi pembelajaran yang dipelajarinya. Kita akan lebih puas lagi apabila peserta didik juga termotivasi untuk berbagi pengetahuan/ pendapatnya dengan orang lain. Dalam kaitan ini, petunjuk belajar yang disarankan untuk diberikan kepada peserta didik adalah misalnya memotivasi peserta didik untuk mendiskusikan topik tertentu yang berkaitan dengan materi pembelajaran yang telah dipelajari. Yang 
menjadi penekanan di sini adalah yang berkaitan dengan aspek "probing" (pendalaman) atau "problem solving". Berikut ini diberikan sebuah contoh petunjuk belajar tentang dorongan atau motivasi bagi peserta didik untuk berbagi pengalaman atau pengetahuannya dengan sesama temannya.

Contoh petunjuk belajar yang bertujuan untuk mendorong/memotivasi peserta didik agar tergerak hati dan pikirannya berbagi pengetahuan/ pendapatnya dengan orang lain.

Anda telah mempelajari apa yang dimaksudkan dengan bahan belajar mandiri atau modul. Apakah buku teks yang dipelajari peserta didik secara individual dapat disebut sebagai modul? Apa alasannya? Cobalah Anda diskusikan pertanyaan ini dengan temanmu. Jangan lupa menyerahkan hasil diskusi Anda kepada tutor/fasilitator pada pertemuan yang akan datang.

d) Menggugah hati dan pemikiran peserta didik untuk menggali berbagai sumber (referensi) yang berkaitan dengan materi pelajaran yang sedang dipelajari sehingga akan dapat memperluas wawasannya Penguasaan peserta didik terhadap materi pelajaran akan semakin mantap apabila peserta didik didorong untuk mengemukakan pendapatnya melalui pembuatan paper satu halaman (a one-page paper). Untuk melaksanakan tugas ini, peserta didik tentunya akan menggali berbagai sumber/referensi, baik yang berupa media cetak maupun melalui diskusi dengan sesama teman atau beberapa nara sumber yang relevan yang dapat ditemui. 
Berikut ini diberikan contoh petunjuk belajar yang bertujuan menggugah hati dan pemikiran peserta didik agar termotivasi untuk menggali berbagai sumber (referensi) yang akan dapat memperluas wawasannya.

Kita baru saja selesai membahas materi pelajaran tentang modul. Modul merupakan salah satu jenis media pembelajaran. Tentunya sekarang Anda telah mengetahui apa yang menjadi karakteristik modul. Nah, untuk memperluas wawasan Anda mengenai media pembelajaran atau media sebagai sumber belajar, cobalah buat paper satu halaman (a one-page paper) tentang salah satu jenis media pembelajaran lainnya.

Di dalam paper tersebut, cobalah kemukakan juga kelebihan dan keterbatasan media yang Anda tuliskan. Gunakanlah berbagai referensi dan nara sumber. Lebih cepat Anda menyelesaikan dan menyerahkannya kepada tutor/fasilitator akan semakin baik. Selamat mengerjakan tugas dan semoga berhasil.

e) Mendorong peserta didik untuk melakukan kajian (reviu) terhadap materi pembelajaran yang telah selesai dipelajarinya

Petunjuk belajar yang diberikan kepada peserta didik perlu dibuat bervariasi. Harapannya adalah agar peserta didik tidak merasa bosan. Peserta didik akan senantiasa mendapatkan suatu tugas yang berbeda dengan yang sebelumnya (baru). Dalam kaitan ini, petunjuk belajarnya dapat berupa peserta didik diminta untuk melengkapi sebuah pernyataan. Untuk dapat melengkapi pernyataan yang diberikan, peserta didik harus mereviu materi pembelajaran 
yang telah dipelajari sebelumnya. Diharapkan melalui petunjuk belajar yang demikian ini, maka pemahaman peserta didik tentang materi pembelajaran tertentu yang diuraikan di dalam modul akan semakin jelas dan daya retensinya tentu akan relatif lebih lama.

Berikut ini diberikan sebuah contoh petunjuk belajar yang bertujuan memotivasi atau mendorong peserta didik untuk melakukan kajian (reviu) terhadap materi pembelajaran yang telah selesai dipelajarinya.

Untuk lebih meyakinkan diri Anda mengenai konsep tentang modul, cobalah lengkapi pernyataan yang terdapat pada kotak berikut ini.

Bahan belajar mandiri (modul) adalah bahan belajar utama pada pendidikan atau pelatihan jarak jauh yang dirancang khusus secara professional agar dapat dipelajari oleh peserta didik, baik secara individual maupun kelompok. Karakteristik modul adalah

f) Mendorong peserta didik untuk melakukan kegiatan praktek

Haruslah dihindarkan pemberian petunjuk belajar yang tidak mungkin dilakukan peserta didik, misalnya saja, meminta peserta didik untuk melakukan kerja praktek. Petunjuk belajar yang demikian ini akan sulit dilaksanakan dan kalaupun dilaksanakan akan menyita waktu yang relatif banyak di samping akan 
dapat menurunkan motivasi/semangat belajar peserta didik. Tujuannya memang sangat baik tetapi keterlaksanaannya dan dampaknya perlu menjadi pertimbangan bagi para penulis modul.

Sekalipun demikian, petunjuk belajar yang menuntut kerja praktek masih dapat dipertimbangkan apabila sifatnya masih cukup sederhana dan tidak terlalu membutuhkan banyak persyaratan dan waktunya juga tidak terlalu lama. Apabila memerlukan peralatan hendaknya peralatan yang terdapat di lingkungan rumah tangga (Lasmono, 2000). Sebagai contoh misalnya adalah yang berupa praktek melakukan kegiatan diskusi dengan 4 atau 5 orang peserta didik mengenai topik tertentu, atau mewawancarai nara sumber atau orang tertentu lainnya yang terdapat di kalangan masyarakat dan kemudian menuliskan hasilnya.

Sejauh ini, Anda telah berhasil mempelajari topik tentang kiat mempelajari modul yang berhasil. Nah, untuk mengetahui berbagai kiat mempelajari modul yang berhasil, ajaklah 4 atau 5 teman dan diskusikanlah kiat-kiat mempelajari modul yang berhasil. Bagilah pengetahuan atau pengalaman tentang kiat mempelajari modul yang telah membuat Anda berhasil belajar. Percayalah bahwa melalui diskusi, maka Anda akan lebih percaya dan sekaligus juga membantu sesama teman sehingga turut berhasil belajar.

\section{Langkah-Langkah Mempelajari Modul}

Ada beberapa langkah pemanfaatan yang harus diikuti oleh peserta didik atau siapa saja yang akan melakukan kegiatan belajar dengan menggunakan modul. Bagi peserta didik di 
lingkungan pendidikan persekolahan, langkah-langkah kegiatan belajar dengan menggunakan modul seyogianya sudah dijelaskan pada pertemuan awal program pembelajaran dimulai (orientasi kegiatan belajar). Berbeda halnya dengan program pembelajaran yang diikuti oleh orang dewasa. Pada program pendidikan jarak jauh yang diikuti oleh orang dewasa, maka langkah-langkah kegiatan belajar yang telah dirumuskan di dalam modul tentunya dapat dipelajari sendiri oleh peserta didik. Artinya, tidak perlu dijelaskan secara verbal dan khusus dalam pertemuan awal (orientasi kegiatan belajar).

Strategi belajar pada pendidikan jarak jauh adalah belajar mandiri tanpa ada ketergantungan pada orang lain dan kalaupun bantuan orang lain dibutuhkan, bantuan tersebut sangat minimal. Itulah sebabnya mengapa petunjuk belajar di dalam modul sangat penting dan turut menentukan keberhasilan peserta didik belajar. Selanjutnya, langkah-langkah kegiatan belajar selama mempelajari modul yang dimaksudkan dapat diuraikan sebagai berikut:

a. Mempelajari petunjuk belajar yang terdapat di bagian PENDAHULUAN pada setiap modul

Sewaktu peserta didik mengikuti orientasi kegiatan belajar, kepada peserta didik juga sudah disampaikan daftar modul yang akan dipelajari selama satu semester atau satu tahun. Seyogianya memang modul perdana yang perlu diberikan kepada peserta didik pada waktu orientasi kegiatan belajar. Pemberian modul-modul berikutnya akan sepenuhnya ditentukan oleh kecepatan belajar masing-masing peserta didik sendiri dalam memahami materi pembelajaran yang dibahas di dalam setiap modul.

Sewaktu peserta didik memegang modul perdana, maka tutor/fasilitator meminta peserta didik untuk membacanya secara cermat. Kemudian, tutor/fasilitator melakukan konfirmasi dengan menanyakan kepada peserta didik tentang 
informasi apa saja yang diuraikan di dalam bagian PENDAHULUAN yang telah mereka baca. Setelah konfirmasi dilakukan, tutor/fasilitator memberikan penekanan-penekanan yang perlu diperhatikan dan dilaksanakan peserta didik, antara lain yaitu memperhatikan dan menerapkan petunjuk belajar yang diberikan dan melakukan dengan sebaik-baiknya penugasan apapun yang diminta di dalam modul untuk dilakukan peserta didik.

b. Mempelajari Materi Pembelajaran Kegiatan Belajar 1

Setelah mempelajari petunjuk pemanfaatan modul (petunjuk belajar) yang terdapat pada bagian PENDAHULUAN, secara garis besar, peserta didik sudah tahu cara-cara mempelajari modul, kompetensi yang diharapkan dapat dikuasai, dan evaluasi terhadap hasil belajar yang mereka lakukan. Petunjuk belajar yang lebih khusus diberikan pada bagian "Pengantar" yang terdapat pada masing-masing Kegiatan Belajar. Demikianlah halnya sewaktu peserta didik akan memulai aktivitas belajarnya pada Kegiatan Belajar 1. Peserta didik ditekankan untuk memahami penjelasan yang diberikan pada bagian "Pengantar".

Dengan mempelajari penjelasan pada bagian "Pengantar", maka peserta didik dapat mengetahui dengan jelas kompetensi yang akan dikuasainya setelah selesai mempelajari materi pembelajaran pada Kegiatan Belajar 1. Selain kompetensi yang akan dikuasai, kepada peserta didik juga diinformasikan tentang sejauh mana ruang lingkup materi pembelajaran yang akan dipelajarinya dan persyaratan apa saja yang harus dipenuhi peserta didik untuk dapat melanjutkan kegiatan belajarnya pada Kegiatan Belajar 2. Jika penjelasan pada bagian "Pengantar" telah dapat dipahami peserta didik secara jelas, maka barulah peserta didik mulai mempelajari materi pembelajaran yang diuraikan pada bagian Uraian Materi. 
Mempelajari materi yang diuraikan di dalam setiap Kegiatan Belajar hendaklah dilakukan tahap demi tahap sampai peserta didik benar-benar telah menguasainya. Bila perlu, peserta didik dapat saja membuat catatan kecil tentang halhal tertentu yang kemungkinan tidak atau sulit dipahaminya. Jika di dalam mempelajari uraian materi pembelajaran, peserta didik diminta untuk melakukan sesuatu, misalnya menulis, maka hendaknya peserta didik melakukan hal tersebut.

Janganlah sekali-kali ada anggapan bahwa penugasan yang diminta di dalam modul untuk dilakukan peserta didik adalah hal yang kecil sehingga jika tidak dilakukan, tidak akan berdampak apa-apa. Pemikiran yang demikian ini tidaklah benar. Justru jika peserta didik tidak melakukan penugasan yang diminta di dalam modul berarti peserta didik menampik/ membuang peluang yang berharga. Karena itu, penugasan apa saja yang dituntut untuk dilaksanakan, hendaknya peserta didik segera melaksanakannya tanpa perlu harus menundanya atau apalagi melewatkannya begitu saja.

Dengan mengerjakan semua aktivitas belajar sebagaimana yang diminta di dalam modul dan peserta didik mengerjakannya dengan sebaik-baiknya, maka anggota badan (fisik) peserta didik juga melakukan aktivitas. Implikasi lebih jauh adalah bahwa peserta didik tidak hanya mengaktifkan otak (olah pikir) tetapi juga fisiknya ikut diaktifkan sehingga akan dapat mengurangi kejenuhan/ kebosanan belajar. Manfaat lain dari mengaktifkan unsur otak dan bagian fisik dalam kegiatan belajar akan dapat membantu mempermudah peserta didik memahami materi pelajaran yang dipelajarinya.

Setelah peserta didik selesai mempelajari materi pembelajaran pada Kegiatan Belajar 1, maka peserta didik dapat mereviu rangkuman yang diberikan. Dalam hal ini, 
peserta didik mempunyai peluang untuk menambahkan materi rangkuman yang ada apabila memang dirasakan peserta didik ada yang perlu ditambahkan. Dengan adanya rangkuman ini tidaklah berarti bahwa peserta didik cukup hanya mempelajari rangkuman yang ada di dalam modul.

Rangkuman yang diberikan pada setiap Kegiatan Belajar hendaknya disikapi peserta didik sebagai suatu upaya yang membantu mempermudah peserta didik mengambil intisari dari materi pembelajaran yang telah dipelajarinya pada masing-masing Kegiatan Belajar.

\section{c. Mengerjakan Soal-soal Tugas/Latihan}

Di dalam modul, soal-soal tugas/latihan pada umumnya ditempatkan setelah selesai dibahas uraian materi pembelajaran yang terdapat pada Kegiatan Belajar. Sebelum soal-soal tugas/latihan, kepada peserta didik biasanya diberikan sejenis rangkuman atau sinopsis materi pembelajaran yang dibahas pada setiap Kegiatan Belajar. Tentunya dalam hal ini, peserta didik haruslah mempunyai keyakinan bahwa dirinya memang benar-benar telah menguasai materi pembelajaran yang dibahas pada Kegiatan Belajar sebelum mulai mengerjakan soal-soal tugas/latihan. Mengapa?

Pada dasarnya, melalui penyelesaian soal-soal tugas/latihan, setiap peserta didik akan mendapat kesempatan untuk mengukur sendiri tingkat penguasaan dirinya terhadap materi pembelajaran yang telah dipelajarinya (self-assessment). Biasanya, soal-soal tugas/latihan diawali dengan informasi tentang cara-cara mengerjakan soal-soal tugas/ latihan. Sejauh mana masing-masing peserta didik telah berhasil mencapai kompetensi yang telah ditetapkan akan dapat dibuktikan melalui tingkat keberhasilannya mengerjakan soalsoal tugas/latihan. Itulah sebabnya, kepada peserta didik ditekankan agar kegiatan mengerjakan soal-soal tugas/latihan 
dilakukan setelah dirinya yakin benar telah menguasai materi pembelajaran yang telah dipelajarinya.

Memang ada "godaan" bagi peserta didik untuk melakukan "potong kompas" dalam mengerjakan soal-soal tugas/latihan, yaitu dengan melihat Kunci Jawaban yang disediakan di bagian akhir modul. Karena itulah selalu diingatkan di dalam modul agar peserta didik tidak sekali-kali melihat Kunci Jawaban soal-soal tugas/latihan sebelum semua soal selesai dikerjakan. Tujuannya adalah agar peserta didik "tidak menipu" atau merugikan dirinya sendiri tetapi secara jujur akan mengetahui batas/tingkat penguasaannya terhadap materi pembelajaran.

Langkah lebih lanjut adalah bahwa peserta didik diminta untuk bersikap jujur terhadap dirinya sendiri dalam hal tingkat penguasaannya terhadap materi pembelajaran. Seandainya, tingkat penguasaan peserta didik terhadap materi pembelajaran masih belum mencapai batas/tingkat minimal yang ditentukan, maka peserta didik harus sportif sekalipun tidak ada orang lain yang memonitor kegiatan belajarnya. Sportivitas peserta didik juga dituntut untuk melakukan konsekuensi dari belum tercapainya tingkat penguasaan materi pembelajaran yang minimal. Artinya, peserta didik yang bersangkutan harus mempelajari ulang materi pembelajaran yang baru selesai dipelajarinya terutama yang berkaitan dengan materi pembelajaran yang belum dikuasainya.

Manakala peserta didik telah berhasil mengerjakan soal-soal tugas/latihan mencapai tingkat keberhasilan $75 \%$ atau lebih tinggi, maka peserta didik barulah diperkenankan untuk mempelajari materi pembelajaran yang disajikan pada Kegiatan Belajar 2. Kembali lagi dalam hal ini dituntut "sikap jujur" dari setiap peserta didik dalam melaksanakan kegiatan 
belajar mandirinya. Demikian seterusnya sampai semua materi pembelajaran yang terdapat di dalam modul selesai dipelajari peserta didik.

\section{d. Mengerjakan Tes Akhir Modul (TAM)}

Mengerjakan tes hanya dimungkinkan apabila peserta didik telah dapat menyelesaikan sebuah modul dengan baik. Pengertian "berhasil dengan baik" di sini adalah bahwa peserta didik telah mencapai atau mungkin juga bahkan telah melewati batas/tingkat minimal keberhasilan yang ditentukan dalam mengerjakan soal-soal tugas/latihan yang terdapat pada setiap Kegiatan Belajar. Dalam kaitan ini, sportivitas peserta didik untuk kepentingan dirinya sendiri tentunya perlu ditekankan. Artinya, sebelum mengerjakan tes, kepada peserta didik perlu dipertanyakan tentang penguasaannya terhadap materi pembelajaran yang disajikan di dalam sebuah modul di samping kesiapannya sendiri untuk mengerjakan tes.

Sebelum mengerjakan tes, tutor/fasilitator akan memberikan berbagai penjelasan yang penting untuk diketahui peserta didik agar peserta didik dapat dengan tenang mengerjakan tes. Di dalam penjelasan awal ini, para tutor/fasilitator, haruslah menginformasikan kepada peserta didik tentang kesalahan yang ada pada butir-butir tes disertai dengan koreksi perbaikannya sehingga tidak menimbulkan kebingungan peserta didik. Selama mengerjakan tes, peserta didik juga diawasi oleh tutor/fasilitator. Pertanyaan atau kesulitan yang dihadapi peserta didik selama mengerjakan tes dapat langsung ditanyakan/diklarifikasi peserta didik kepada tutor/fasilitator.

Setelah selesai mengerjakan tes, hasil pekerjaan peserta didik diperiksa oleh tutor/ fasilitator dengan menggunakan kunci jawaban. Pemeriksaan hasil pekerjaan peserta didik hendaknya diupayakan dapat diselesaikan dalam waktu yang 
tidak terlalu lama. Tutor/fasilitator hendaknya juga menginformasikan kepada peserta didik mengenai waktu pengembalian hasil tes yang dikerjakan peserta didik. Pada waktu yang ditetapkan, hasil tes dikembalikan kepada peserta didik sehingga peserta didik dapat mengetahui tingkat keberhasilannya mengerjakan tes. Selain itu, peserta didik juga akan mengetahui apakah dirinya sudah diperbolehkan atau belum untuk mempelajari modul berikutnya.

Seandainya hasil tes yang dikerjakan peserta didik belum memungkinkannya untuk mempelajari modul berikutnya, maka secara sportif peserta didik yang bersangkutan haruslah menerimanya. Di samping itu, peserta didik haruslah lebih mempersiapkan dirinya untuk mengerjakan tes untuk yang kedua kalinya. Apabila dalam mengerjakan tes untuk kedua kalinya ini, peserta didik ternyata juga belum mencapai batas/ tingkat minimal untuk boleh mempelajari modul berikutnya, maka peranan tutor/fasilitator sangat diharapkan untuk membantu peserta didik mengatasi kesulitan yang dialaminya.

Materi pembelajaran yang mungkin masih dirasakan peserta didik sulit atau tidak dapat dipahami, maka tutor/fasilitator dituntut untuk bersama-sama mendiskusikannya. Dengan peranan tutor/fasilitator yang sedemikian ini, maka berbagai kesulitan yang dihadapi peserta didik dapat diatasi/ diselesaikan dan sekaligus juga memperjelas pemahaman peserta didik terhadap materi pembelajaran yang dirasakan sulit. Kondisi yang demikian ini akan turut membesarkan hati peserta didik dan diharapkan akan dapat menghindarkan peserta didik dari semangat belajar yang mengendor.

\section{KESIMPULAN DAN SARAN}

Kegiatan pembelajaran pada pendidikan terbuka dan jarak jauh hampir sepenuhnya dilaksanakan peserta didik melalui interaksinya dengan sumber belajar, tanpa atau dengan seminimal mungkin bantuan orang 
lain. Modul atau bahan belajar mandiri merupakan salah satu sumber belajar dan sekaligus juga menjadi bahan belajar utama yang dikembangkan oleh sebagian besar institusi/lembaga penyelenggara pendidikan terbuka dan jarak jauh untuk digunakan membelajarkan para peserta didiknya. Modul tidak hanya berisikan materi pembelajaran (self-contained) tetapi juga memuat berbagai petunjuk/ penjelasan tentang cara-cara mempelajari modul dan ruang atau tempat bagi peserta didik untuk melakukan penilaian sendiri mengenai kemajuan belajarnya (learning guides and steps).

Pengetahuan penulis atau calon penulis modul tentang cara-cara atau petunjuk belajar dan langkah-langkah mempelajari modul sangat diperlukan agar modul yang dihasilkannya memang dapat lebih mudah dipelajari oleh peserta didik. Cara-cara atau petunjuk belajar dan langkah-langkah mempelajari modul tidak hanya diberikan pada bagian PENDAHULUAN modul tetapi juga pada bagian URAIAN MATERI modul. Cara-cara atau petunjuk belajar dan langkah-langkah mempelajari modul merupakan salah satu upaya penulis modul memotivasi/mendorong peserta didik untuk aktif mempelajari modul termasuk mengerjakan soal-soal latihan/tugas dan tes. Perumusan cara-cara atau petunjuk belajar dan langkah-langkah mempelajari modul dinilai sangat penting dalam menentukan keberhasilan peserta didik belajar. Terlebih lagi apabila modul ditujukan kepada peserta didik usia pendidikan dasar dan menengah. Esensi kegiatan belajar yang demikian inilah yang harus benar-benar diperhatikan oleh penulis modul.

Apabila peserta didik usia sekolah dasar dan menengah yang ditargetkan sebagai sasaran yang akan mempelajari modul, maka di samping cara-cara atau petunjuk belajar dan langkah-langkah mempelajari modul yang dirumuskan secara sederhana dan jelas, maka modul hendaknya juga menggunakan (1) banyak ilustrasi (kaya dengan ilustrasi), (2) kalimat-kalimat sederhana, (3) contoh-contoh yang memperjelas uraian materi pelajaran, dan (4) titian belajar (dimulai dengan uraian meteri pelajaran yang lebih mudah). Aspek teknis yang juga penting adalah yang berkaitan dengan perwajahan modul. 


\section{KEPUSTAKAAN}

Andamsari. (2000). “Aktivitas Belajar dalam Modul” sebagai bagian dari Modul Pelatihan Penyusunan Modul. Jakarta: Pusat Teknologi Komunikasi dan Informasi Pendidikan.

Haryono, Anung. (2001). Self-learning Materials (Module): The Concept and Format. Module. Presented in the training on "Self-Learning Materials Development", conducted by SEAMEO SEAMOLEC under the sponsorship of Japan-ASEAN Solidarity through ASEAN Foundation. Jakarta: SEAMEO SEAMOLEC.

Inten, Wayan. (2000). "Penggunaan Bahasa dalam Modul” sebagai bagian dari Modul Pelatihan Penyusunan Modul. Jakarta: Pusat

Teknologi Komunikasi dan Informasi Pendidikan.

Lasmono, Suharto. (2000). "Petunjuk Belajar dalam Modul” sebagai bagian dari Modul Pelatihan Penyusunan Modul. Jakarta: Pusat Teknologi Komunikasi dan Informasi Pendidikan.

Purwanto. (2000). “Perancangan dan Penggunaan Ilustrasi” sebagai bagian dari Modul Pelatihan Penyusunan Modul. Jakarta: Pusat

Teknologi Komunikasi dan Informasi Pendidikan.

Rahardjo, Raphael. (2001). Promoting Active Learning. Module.

Presented in the training on "Self-Learning Materials Development", conducted by SEAMEO SEAMOLEC under the sponsorship of JapanASEAN Solidarity through ASEAN Foundation. Jakarta: SEAMEO SEAMOLEC.

Sadiman, Arief S. (ed.). (1987). Course Development: A Manual for Editors of Distance-Teaching Materials. Second Edition. Diterjemahkan oleh Anung Haryono. Cambridge: International Extension College.

Siahaan, Sudirman. (2004). Modul tentang Menulis Modul. Disajikan pada pelatihan "Dasar-dasar Penulisan Modul" bagi guru-guru Sekolah Menengah Ekonomi tingkat Atas (SMEA) di lingkungan Majelis Pendidikan Kristen (MPK). Salatiga, Jawa Tengah: Majelis Pendidikan Kristen. 